\title{
Corporate Governance and Dividend Smoothing: Evidence from Pakistani Listed Banks
}

\author{
Zahid Ali*, Yang Hanming and Assad Ullah
}

\begin{abstract}
Manuscript type: Research paper

Research aims: This paper empirically examines the effects of ownership and board structure on dividend smoothing in Pakistani listed banks between 2006 and 2014.

Design/Methodology/Approach: This study employs random Tobit regression to analyse the effects of ownership and board structure on dividend smoothing. It also applies principal component analysis (PCA) to develop a corporate governance index.

Research findings: The findings indicate that Pakistani banks with concentrated and foreign ownership, small size audit committee and less independent boards, exhibit higher levels of dividend smoothing. Interestingly, the study finds Pakistani banks having a joint position of CEO and chairperson, demonstrate lesser dividend smoothing. The study concludes that increasing dividends is an alternative monitoring mechanism for shareholders who are enclosed within a weak corporate governance environment such as Pakistan.

Theoretical contribution/Originality: This study contributes to previous literature on corporate governance and dividend smoothing by investigating the role of the boards and the ownership structure. It also fills the research gap by investigating the impact of corporate governance on dividend smoothing by using the CG-Index.
\end{abstract}

\footnotetext{
* Corresponding author: Zahid Ali is a Lecturer at the Department of Management Studies, University of Malakand, Pakistan. He is also a PhD scholar at the School of Accounting, Zhongnan University of Economics and Law, Wuhan, Hubei, China. Email: zahidzady@yahoo.com Yang Hanming is a Lecturer at the School of Accounting, Zhongnan University of Economics and Law, Wuhan, Hubei, China. Email: hanming_10@aliyun.com

Assad Ullah is a Lecturer at the School of Management, Huangzhong University of Science and Technology, Wuhan, Hubei, China. Email: assad@hust.edu.cn
}

https://doi.org/10.22452/ajba.vol11no2.3 
Practitioner/Policy implications: The findings of this study offer practical implications for payout and corporate governance policies. Higher information asymmetry and regulatory requirements, low shareholders' rights and weak corporate governance environment make dividend smoothing another tool for safeguarding the interest of minority shareholders in Pakistani listed banks. Currently, regulators in Pakistan are only focusing on corporate governance mechanism as a means of protecting shareholders. This study recommends that smooth dividends can serve as an additional instrument to help safeguard the minority shareholders' interest from expropriation.

Research limitation: The findings of this study may not be generalised due to the small sample size.

Keywords: Dividend Smoothing, Corporate Governance, Tobit Regression, Principal Component Analysis, Pakistan

JEL Classification: G350, G300, C24, C19

\section{Introduction}

Dividends are one of the returns earned by shareholders through their investment. The dividends announced by a firm may attract investors. This may increase the demand of the firm's stocks and so affect its share price significantly (Gordon, 1963). However, if the firm announces an increase in dividends by compromising future investment projects, the market will react negatively (Litzenberger \& Ramaswamy, 1982). Many scholars (e.g. Lintner, 1956; Javakhadze, Ferris, \& Sen, 2014; Baker \& Kapoor, 2015) have empirically confirmed the positive response towards dividend initiations and the negative response towards dividend omissions and cuts. Market response to dividend cuts and omissions, however, is severe when compared to dividend increase. Therefore, firms are hesitant to cut dividends. Such a situation is so serious that even managers opt for external financing and forgo economically attractive projects in the bid to avoid dividend cuts (Gordon, 1963; Brav, Graham, Harvey, \& Michaely, 2005). The market also tends to give emphasis to premium dividends over stable or consistently increasing dividends. Consequently, the management tends to put efforts into achieving the smoothness of dividends (Lintner, 1956).

The concept of dividend smoothing is rooted in Lintner (1956) who documented that offering shareholders with predictable dividends is 
more rewarding than offering them dramatic changes of dividends. This is achieved by maintaining the target dividend payout ratio and adjusting their dividend policy towards this target. Dividends are adjusted partially to their earnings so as to avoid any erratic changes. This is because shareholders prefer stable payments over volatile dividends. Lintner's (1956) findings were empirically confirmed by subsequent studies (e.g. Fudenberg \& Tirole, 1995; Leary \& Michaely, 2011; Jeong, 2011, 2013; Javakhadze et al., 2014; Hussain \& Shah, 2015) which proposed a number of theoretical explanations such as the agency and informational asymmetry theories.

The agency theory deduces that dividend smoothing helps to mitigate agency conflict between managers and shareholders. Firms suffering greater agency conflict are more likely to practice dividend smoothing. In comparison, the informational asymmetry theory observes that a firm's dividend policy can assist in conveying the information held by insiders with regards to the firm's future prospects. Firms experiencing greater informational asymmetry will need to exhibit greater dividend smoothing so as to enable investors to evaluate the firm's earning ability and value.

Despite substantial empirical evidence (e.g. Leary \& Michaely, 2011) and theoretical explanations, a majority of these studies were conducted using the data of developed countries. Hence, it is doubtful whether the practice of dividend smoothing is peculiar to the developed economies or are they also pronounced in emerging economies where the tax and the institutional and economical environments are different. Noticing this disparity, the current study, hence aims to investigate the dividend smoothing practice of banking institutions in Pakistan. Several distinct economic and institutional features place the Pakistani banking sector as a unique and interesting environment to examine the stability of the dividend policy. For instance, over the years, the phenomenon of globalisation, bank privatisation and technological advancement in Pakistan have exposed the country's banking sector to higher risks. Compared to the non-financial sectors, the agency problem in the banking sector is not confined to just manager-shareholder conflicts but also other issues. As an example, banks are operated by the depositors' funds. This makes it vital for the banks to safeguard the interest of the depositors as well as the shareholders. Pakistani banks are regulated by the State Bank of Pakistan (SBP) which is governed by the Corporate Governance Act 2013, coupled with augmented regulations. 
Pakistani banks are required to seek the SBP's prior approval for the appointment of their CEOs and directors. In addition, appointed executive directors cannot exceed one-fourth of the board size and the bank's key executives are not allowed to hold any position in other financial institutions (SBP, 2006). In this regard, Pakistani banks are more vulnerable to agency risks which are mitigated externally through additional governance. Majority of the dividend smoothing literature have been restricted to looking at the firm's financial characteristics only (e.g. Jeong, 2011, 2013). Very few studies (e.g. Javakhadze et al., 2014) have addressed the relationship of firm ownership and board structure in the context of dividend smoothing. Studies on dividend smoothing (Leary \& Michaely, 2011; Jeong, 2011, 2013; Javakhadze et al., 2014) also seemed to concentrate on non-financial sectors. To the best of our knowledge, the banking sector of Pakistan has not been explored. Additionally, local corporate governance scandals such as the Mehran and Crescent banks in Pakistan have motivated the interest to examine whether or not scandals of this nature can be avoided by committing to large smooth dividends. To address the gap in literature, this study will relate board and ownership structure to dividend smoothing in Pakistani listed banks.

This study specifically aims to determine if dividend smoothing can be accomplished through the agency risk alleviation or by reducing information asymmetry between managers and outsiders. It thus investigates the role of corporate governance in the context of dividend smoothing, i.e., whether dividend smoothing is the substitute or the outcome of good corporate governance. This study particularly examines the effect of the board and ownership structure on dividend smoothing for banks listed on the Karachi Stock Exchange (KSE). It thus offers a comprehensive analysis of the major aspects of dividend smoothing in light of the agency and signaling theories. It commences by addressing the joint impact of corporate governance measured via CGindex developed through the principal component analysis.

The remainder of this paper is organised as follows: Section 2 reviews the literature relating to corporate governance and dividend smoothing. Section 3 develops the hypotheses. Section 4 describes the methodology employed. Section 5 presents the summary statistics for the payment of dividends, and also reports on some descriptive statistics for the samples. Section 6 concludes by discussing the research findings, implications and limitations of the study. 


\section{Literature Review}

\subsection{Dividend Smoothing Theories}

Dividend smoothing was developed by Lintner (1956) about 60 years ago. It was tested in various empirical studies (e.g. Fudenberg \& Tirole, 1995; Leary \& Michaely, 2011; Jeong, 2011, 2013; Javakhadze et al., 2014; Hussain \& Shah, 2015) but despite the substantial empirical evidence recorded on dividend smoothing, there has been little consensus over why some firms smooth more than others. In this section, models relating to dividend smoothing are presented. These models can be broadly divided into two categories based on the market fractions: the asymmetric information-based model and the agency problem model.

In the context of the asymmetric information-based model, firms may use dividends as signals to convey their private information about current and future earnings (Jeong, 2011; Leary \& Michaely, 2011). Using dividends as signals is more pronounced when there is higher information asymmetry between the managers and shareholders or between the informed and uninformed investors. Therefore, young opaque firms with few growth opportunities and less tangible assets will exhibit a higher degree of dividend smoothing (Jeong, 2011; Leary \& Michaely, 2011). Outside shareholders develop their expectations about firm's earnings based on the firm's cash flows. These shareholders tend to give more weight to recent earnings. This occurrence helps to protect managers from being fired through the dividend smoothing process, in other words, underreporting today's performance to enable themselves for future's over reporting (DeMarzo \& Sannikov, 2008). Despite this, the degree of smoothing is expected to decline over time with the amount of information generated by the market analyst and then publicised by corporations, which tend to increase significantly due to rapid information technology and market sophistication (Leary \& Michaely, 2011).

From the perspective of agency costs, Jensen (1986) asserted that managers with substantial free cash flow can increase dividends. They can thus pay out cash that could otherwise be invested in low-return projects or be wasted. In other words, higher dividends may reduce the agency costs of free cash flow. Easterbrook (1984) and Jensen (1986) highlighted that commitment to pay large stable dividends causes firms to raise finances from external markets which act as a barometer for disciplining them. This exposure to the external market helps firms to diminish the agency costs. Lower levels of leverage provide firms with financial flexibility but it simultaneously exposes them to agency 
costs. Mature firms with high smooth dividends are exposed to a lower level of agency costs without affecting their access to low-cost external finances. Allen, Bernardo and Welch (2000) reported that for institutional investors to be better monitors, they can be attracted by large smooth dividends because of their dividend tax advantage. The authors added that once the firms are able to attract institutional investors, they can put a penalty for any decrease or dividend omission, in other words, follow the managerial rent-seeking behaviour. Lambrecht and Myers (2010) affirmed this behaviour of managers in the context of smooth dividends. They reported that managers demanded smooth dividends because of their risk aversion and rent-seeking behaviour. The high level of dividends is associated with the shareholder's weak rights. According to Javakhadze et al. (2014), the types of shareholders can influence the dividend smoothing behaviour. It appears that government controlled firms were expected to suffer highly from the agency problem as these firms were owned by the citizens. Since citizens only form as indirect shareholders for this type of company, they are believed to have little incentive in monitoring the management. Hence, managers of these firms will desire a stable dividend policy with high rates so as to keep their principals happy.

\subsection{Corporate Governance and Dividend Smoothing in Pakistan}

Lazarides, Drimpetas and Dimitrios (2009) referred to corporate governance as the way in which corporations were governed. Corporate governance strives to protect shareholders and other stakeholders' interest by ensuring transparency and enforcing accountability within corporations. Ur Rehman and Mangla (2010) found empirical evidence of corporate governance impacting on the performance of financial institutions has enticed regulators to ensure good corporate governance practices in Pakistan (SBP, 2006). According to the SBP's handbook, "Corporate governance is the system by which business corporations are directed and controlled by structuring the rights and responsibilities of different participants within a corporation such as boards, managers, shareholders and stakeholders. Doing so, provides structure for setting corporate objectives and for mustering resources to attain those goals without compromising fairness, ethics, transparency and accountability". Similarly, the International Finance Corporation (IFC, 2016) stated that, "Corporate governance is the structure and process by which companies are directed and controlled". Corporations with good governance 
operate efficiently; they have easy access to the capital market; they diversify risks and they have fewer chances of mismanagement than their counterparts. Good governance improves accountability and transparency in corporations; it enables them to respond to stakeholders' concerns effectively. Good governance also plays a role in economic development by attracting new investments and creating employment avenues through improving capital access (IFC, 2016).

International scandals like Parmalat, WorldCom, Enron, Ahold as well as other local corporate governance scandals such as Pakistan Telecommunication Company Limited's privatisation, the National Insurance Company Limited, Pakistan Railway (Fatima, 2016) have raised issues regarding corporate governance in Pakistan. In this regard, issues relating to independent boards, external candidature for CEOs, increasing CEO compensations, CEOs' shorter tenures and CEOs' lower prerequisite consumptions are all recent corporate governance trends set within the world (Hermalin, 2005). Since the financial sector in developing countries is flimsier than those of developed countries, it would seem that they cannot afford to have corporate scandals as big as those like Enron.

In Pakistan, the financial sector contributes to approximately 52 per cent of its GDP (Rehman, Hasan, Mangla, \& Sultana, 2012). While Reaz and Arun (2006) have highlighted the importance of good corporate governance in the financial sector of Bangladesh and its GDP, Ur Rehman and Mangla (2010) noted that corporate governance impacts the performance of both Islamic and conventional banks in Pakistan. Linked to this, Rehman et al. (2012) found that there was a positive association of large boards with bank performance in Pakistan.

Global corporate governance scandals have forced regulators in Pakistan to strive for a strong corporate governance culture. The State Bank of Pakistan (SBP) and the Securities and Exchange Commission of Pakistan (SECP) are striving for good corporate governance culture by establishing standard auditing and disclosure requirements and promoting ethical values. Despite these efforts, more needs to be done because corporate governance in Pakistan is weak in the areas involving the board's monitoring capacity, policy formulation, board committee's performance, internal control environment and also internal audit (SBP, 2006). In this respect, the SECP recently issued corporate governance guidelines in 2013, under which listed firms are governed.

In a weak corporate governance environment where the compliance level is low, dividends can be used as a source to alleviate agency costs 
(Al-Malkawi, 2005). Since the dividend-paying behaviour in developing countries is different from that of developed countries due to the difference in tax, information asymmetry and market volatility (AlKuwari, 2009; Wardhana, Tandelilin, Wayan Nuka Lantara, \& Junarsin, 2014), it is likely that dividends are more susceptible in playing the monitoring role which then enable minority shareholders to control the managers and large shareholders. Iqbal (2013) found that Pakistani firms' board independence and non-CEO duality tend to reduce chances of dividends announcement.

High and stable dividends are good sources for alleviating agency costs (Easterbrook, 1984; Jensen, 1986). Firms that are exposed to high agency costs exhibit higher degrees of dividend smoothing while weakly governed firms tend to opt for a higher degree of dividend smoothing (Leary \& Michaely, 2011; Javakhadze et al., 2014). This is an occurrence where corporate governance and dividend smoothing serve as each other's substitutes. However, some authors (Kowalewski, Stetsyuk, \& Talavera, 2007) believe that by virtue of their strong rights, shareholders are able to influence the firm's payout policy; they can also ask for high and stable dividends where dividend smoothing becomes the outcome of a strong corporate governance.

Regular and stable payout policies have a two-way effect on companies. The smooth dividends declared by firms reduce the chances of expropriation by management while simultaneously also exposing these firms to the external financial market. They not only act as barometers but may also affect financial costs. Therefore, firms always try to strike the optimal dividend policy and an appropriate level of dividend smoothing.

Firms operating in an environment with weak shareholder rights such as those in Pakistan tend to pay smooth dividends (Javakhadze et al., 2014). Similarly, firms with weak corporate governance, follow a high dividend policy where dividends act as a substitution of corporate governance. In other words, the link between corporate governance and dividends is negative (Sawicki, 2009). From their study, Javakhadze et al. (2014) found that companies with strong corporate governance exhibited less dividend smoothing. Likewise, Leary and Michaely (2011) emphasised that companies with weak corporate governance exhibited more dividend smoothing. They noted that firms with weak growth potentials and corporate governance have greater proportions held by institutions going for higher dividend smoothing. 
Literature (e.g. Leary \& Michaely, 2011; Jeong, 2011, 2013) highlights the influencing role of corporate governance on dividend smoothing, particularly for those companies that are in emerging economies such as Pakistan. Following previous empirical works of Leary and Michaely (2011) and Javakhadze et al. (2014), this study incorporates board independence and ownership concentration as proxies for corporate governance. This study extends on existing literature by including other pertinent proxies such as board size, CEO/chairperson duality and audit committee size. The following section discusses the hypotheses development.

\section{Hypotheses Development}

Fama and Jensen (1983) argued that the board of directors makes significant efforts to reduce the agency problem. This is because the central focus of corporate governance is to monitor the executive management. Nonetheless, boards can only effectively monitor and take corrective actions if they have enough representation of the independent directors (Jensen, 1993; Setia-Atmaja, Tanewski, \& Skully, 2009). According to Jensen (1993) and Yermack (1996), large boards may not always be efficient monitors. Large boards have the issue of coordination among the board members; therefore small boards with enough proportion of independent directors are more efficient in monitoring the executive management. Based on Jensen's (1993) argument, it would seem that large boards are indicators of weak monitoring. In this regard, firms with large boards were more exposed to the agency problem and would have more tendency to smooth their dividends.

Most firms in Pakistan are controlled by families, thus they may perceive independent directors as a threat to family control. In this regard, it is expected that large boards in Pakistan will have weak monitoring roles and alternatively, will monitor through large and smooth dividends (La Porta, Lopez-de-Silanes, Shleifer, Vishny, 2000). Based on this, this study posits that:

$\mathrm{H}_{1}$ : Board size and dividend smoothing in Pakistani banks are positively associated.

Boards with CEO duality and those crowded by executive directors would not be good monitors and may not challenge management decisions (Jensen, 1993). Since 2017, firms operating in Pakistan must have a majority of independent directors on their boards (SECP, 2013). 
Merely electing non-executive directors onto boards may not serve well as they cannot always challenge the management although they are able to safeguard their self-interests. As a result of this, the SECP took to addressing the characteristics of independent directors in its 2013 ruling. It proposed that independent directors can serve as good monitors and also safeguard shareholders' interest better (Jensen \& Meckling, 1976; Sharma, 2011; Armstrong, Core, \& Guay, 2014). They can give independent judgment without being influenced by the management (Fama \& Jensen 1983; Lehn, Patro, \& Zhao, 2009), thereby avoiding agency conflict which occurs because of the management-ownership conflict (type I agency problem) or as a result of the conflict of interest between minority and controlling shareholders (type II agency problem) (Bebchuk \& Weisbach, 2010; Florackis, Kanas, \& Kostakis, 2015). Thus, independent boards can safeguard the interests of minority shareholders from being expropriated by major shareholders. This, in turn, helps to reduce both type I and type II agency problems (Raheja, 2005; Sharma, 2011; Armstrong et al., 2014). The stakeholder theory states that independent directors outperform insiders while guarding the interests of stakeholders because they are experienced and have more ethical and legal obligations (Rodriguez-Dominguez, Gallego-Alvarez, GarciaSanchez, 2009).

Studies (Maury \& Pajuste, 2002; Krishna Prasanna, 2014) have indicated that companies with more non-executive directors were less likely to use dividends as a monitoring device for agency cost reduction as they can monitor themselves effectively. Other studies (Ghosh \& Sirmans, 2006) noted that independent directors on the board tend to ask for large dividends in order to counter the use of free cash flows for selfinterests. The current study takes the notion that independent directors are effective monitors who can challenge management decisions, hence independent boards can serve as an effective channel for good corporate governance. It would appear that the demand for smooth dividends diminishes when the company elects more independent directors onto its board. Based on this, the current study hypothesises that:

$\mathrm{H}_{2}$ : Board independence is negatively associated with dividend smoothing in Pakistani banks.

The audit committee is a standing committee that consists of nonexecutive directors of the board. It has a vital role in good corporate governance. The audit committee of the company is in the best position to identify any overruling by the management and to react immediately. 
Nevertheless, the audit committee should be chaired by a non-executive director; it should be crowded by independent directors (SECP, 2013). Neither the chairperson nor the CEO could be its member. The audit committee has various responsibilities comprising the reviewing of the internal audit department, the audit plans as well as the annual and audit reports of the company. It also needs to look after the appointment of external auditors, review the accounting control and protect company assets (Setia-Atmaja et al., 2009). It also has to make recommendations about related party transactions to the board of directors (SECP, 2013).

The primary purpose of the audit committee is to safeguard the shareholders' interest. McMullen (1996) have noted that reliable information is linked with the presence of the audit committee. The audit committee's independence is positively linked to the private benefits of the management (Setia-Atmaja et al., 2009). The audit committee's independence safeguards minority shareholders from expropriation i.e., it reduces agency problem (Raheja, 2005). Based on the above argument, dividend smoothing is expected to play a substitution role for good governance. Therefore, it is expected that as long as the audit committee's independence is increased, the company will be able to reduce agency problems and so, will have less information asymmetry. The SECP compels banks to maintain a majority of independent directors in their audit committee, thus the audit committee's size is directly linked to its independence. Based on this, it is hypothesised that:

$\mathrm{H}_{3}$ : Pakistani banks with large audit committees smooth their dividends less.

As chief executive officer, CEOs are important but CEOs who also act as chairpersons are more powerful. They can dominate board decisions. In such situations, the CEO may disagree with the external (outside) directors, thereby compromising the monitoring role of the board. On the other hand in case of CEO-duality, CEO is also involved in the process of self-evaluation (Petra, 2002). To prevent this, the CEO and the chairperson positions need to be separated (Fama \& Jensen, 1983). According to the entrenchment hypothesis, companies with CEOduality influence the monitoring ability of the board. This can lead to higher information asymmetry and expose firms to greater agency problems which then causes frequent large cash dividends (Ghosh \& Sirmans, 2006; McGuinness, Lam, \& Vieito, 2015). However, the stewardship hypothesis argues that most of the time, the CEO is a well- 
informed person in the organisation and that he/she does not occupy this joint position intentionally. It is possibly due to his/her position as the clearest visionary person in the company that the duality may yield a better performance (Peng, Zhang, \& Li, 2007). Firms with CEO/ chairperson duality concentrates on reinvestment policies, thus under the stewardship view, companies with CEO duality pay dividends less frequently and will also smooth dividends less (Zhang, 2008).

Since most firms in Pakistan are controlled by families, it is expected that the $\mathrm{CEO} /$ chairperson duality will affect the monitoring power of the board which can result in greater agency problem and higher information asymmetry. As a consequence, a high level of dividend smoothing is expected under the entrenchment view. Thus, it is hypothesised that:

$\mathrm{H}_{4}$ : The CEO-duality is positively associated with dividend smoothing in banks.

Based on the agency theory, companies with low management ownership are exposed to severe agency conflict. Such conflict is alternatively reduced by paying high dividends, according to the substitution hypothesis (La Porta et al., 2000). CEOs with more equity ownership opt for low dividends because of greater alignment while entrenched CEOs (CEOs acting as chairpersons, having long tenures, can influence boards with more ownership) pay low dividends (Ghosh \& Sirmans, 2006). Similarly, companies with director's stock options do not need an external mechanism for using dividends to reduce the agency conflict. This finding has been consistent for firms with excessive free cash (Boumosleh \& Cline, 2015).

Two views regarding management ownership and dividends are pertinent. According to the alignment view, the negative association between management ownership and dividends is expected as firms with high management ownership have greater alignment and ultimately, low agency problems (Lee, 2011; Florackis et al., 2015). However, if the management ownership exceeds a certain level, then, according to the entrenchment hypothesis, expropriation is expected (Farinha, 2003). Pakistani banks have a low level of management ownership, therefore, its alignment effect is expected. The signaling theory states that the cost of false signaling is high for companies with CEO ownership; therefore such companies adopt low payout policies.

Keeping in view the underlying mechanism of both the agency and signaling theory, we postulate that banks with higher management own- 
ership will have higher alignments, face lower level agency problems and ultimately, opt for a low level of dividend smoothing. Hence:

$\mathrm{H}_{5}$ : Pakistani banks having more management ownership will smooth dividends less.

The presence of foreign directors on boards in firms is a common trend these days and Pakistan is no exception (Haque, Jalil, \& Naz, 2007). Foreign directors bring diversity, innovation and uplift the firm's performance (Sharif \& Rashid, 2014). Literature does not depict a very clear image of the association between foreign ownership with dividends but Liljeblom and Maury (2016) reported that foreign ownership is associated with low dividends for Russian firms. They asserted that this finding could be because of the discriminatory tax treatment of foreigners. They also noted that in Russia, dividends were taxed at the rate of 6 per cent for locals and at the rate of 15 per cent for foreigners.

Firms with a high level of foreign ownership have less financial constraints and can recover quickly from any financial distress; therefore, they always prefer a high level of stable dividends. Especially in a politically unstable environment, foreigners desire a quick recovery of their investment, following the rental hypothesis of dividends (Bebczuk, 2005). The association between foreign ownership and dividends was reported to be positive for Korea (Jeong, 2011) where it was noted that foreign investors in Korea have a preference for high dividends. In similar lines, Baba (2009) also found an association of high-level foreign ownership with higher probability and high levels of dividend. It was reported that an increase in foreign ownership lowers the probability of dividends reduction. Therefore, the following hypothesis was formulated:

$\mathrm{H}_{6}$ : Pakistani banks with high foreign ownership exhibit a higher level of dividend smoothing.

The role of ownership structure in dividend smoothing is quite significant (Michaely \& Roberts, 2011). Firms opt for smoothed dividends in order to minimise the agency conflict. Firms facing a high conflict of interest will pay a high and stable dividend in order to minimise those conflicts. Firms with a concentrated ownership have more power to control the management (Shleifer \& Vishny, 1986). They are exposed to a lower level of type I agency problem (managementshareholders conflict). Therefore, large block holders may bear with 
dividend cuts and go for less dividend smoothing. At the same time, however, minority shareholders in such firms are at risk of being expropriated by major shareholders, termed as type II agency problem. Firms with large block holders are exposed to a lower level of type I agency problems but they face a higher level of type II agency problem (Shleifer \& Vishny, 1997). As the ownership structure in Pakistan is characterised by family concentrated ownership (Institute of Cost and Management Accountants of Pakistan, 2011), we therefore expect greater type II agency problems in banks. Thus, it is hypothesised that:

$\mathrm{H}_{7}$ : Pakistani banks with concentrated ownership will have the tendency to smooth dividends more.

\section{Methodology}

\subsection{Sample}

The initial sample is comprised of 34 banks listed on the Karachi Stock Exchange (KSE) over a 9-year period, from 2006 to 2014. The corporate governance data were manually collected from the annual reports of the concerned banks. The financial data of the respective banks were collected from the balance sheet analysis issued by the State Bank of Pakistan while the stock prices data were retrieved from the business recorder. In order to gauge dividend smoothing (measured via SOA), we excluded banks that have never paid dividends. Doing so helped us to avoid any spurious results because dividend smoothing does not arise naturally, rather, it is intended management policy. Doing so also helped us to exclude banks with losses as dividends in Pakistan are only paid out of the corporate's current earnings. We maintained only those banks which have announced dividends for at least three consecutive years. Following this, our final sample comprised of 19 listed Pakistani banks. We took 2006 as the starting year because of the unavailability of corporate governance data prior to 2006.

The list of the 19 banks selected for the study is attached in Appendix 1 which describes those banks. The first column of the table depicts the average dividend per share during the sample period. The second column shows the average board size in terms of the number of directors. The next column reports the proportionate board independence of the banks and the subsequent column specifies the size of the audit committee. The last three columns depict the proportionate 
ownership of the management, foreign and top five shareholders of the banks during the sample period.

\subsection{Speed of Adjustment (SOA)}

For measuring the level of dividend smoothing across the banks, we followed Fama and Babiak (1968) which adopted the modified form of Lintner's (1956) partial adjustment model. Previous studies by Leary and Michaely $(2011)$ and Jeong $(2011,2013)$ have used the Lintner (1956) model which states that:

$$
\begin{aligned}
& \Delta \mathrm{D}=\alpha_{i}+\beta_{1} \mathrm{X}+\mathrm{c}_{i}\left(\gamma_{i} \mathrm{EPS}_{i, t}-\text { Dividend }_{i, t-1}\right)+\varepsilon_{i, t} \\
& \text { or } \\
& \left.\Delta \mathrm{D}=\alpha_{\mathrm{i}}+\beta_{i, 1} \mathrm{EPS}_{i, t}-\beta_{i, 2} \text { Dividend }_{i, t-1}\right)+\varepsilon_{\mathrm{i}, \mathrm{t}}
\end{aligned}
$$

In the above equation $\alpha_{\mathrm{i}}$ is intercept, while $\varepsilon_{\mathrm{i}, \mathrm{t}}$ represents error term. $\mathrm{EPS}_{\mathrm{i}, \mathrm{t}}$ denotes the earnings per share of firm $i$ year $t$. The speed of adjustment (SOA) given by $c_{i}$, theoretically ranges between 0 and 1 . As the SOA approaches 1, the level of dividend smoothing lowers and as the SOA approaches zero, it reflects a higher level of dividend smoothing. $\beta_{\mathrm{i}, 1}=$ $c_{i}$, while $\gamma_{i}$ and $\beta_{i, 2}=-c_{i}$. The above model explains 85 per cent variation in dividends (Lintner 1956). The level of dividend smoothing (SOA) is estimated as $-\beta_{\mathrm{i}, 2}$.

\subsection{Random-Tobit Model}

Conceptually, the SOA lies between zero and one i.e. $0 \leq \mathrm{SOA} \leq 1$ (Leary \& Michaely, 2011). Theoretically, the SOA approaching one means that the banks' dividends move independent of previous dividends and the SOA close to zero shows the practice of higher dividend smoothing (Lintner, 1956). Keeping the nature of the dependent variable (SOA) in view, the ordinary-least-squares (OLS) regression is not an appropriate methodology for analysing dividend smoothing. Any value of the latent variable of $S O A>1$ will be right censored at one while $S O A<0$ will be left censored at zero. Ultimately, there will be two mass points at 0 and 1 in the censored sample. The appropriate methodology adopted here will be censored regression introduced by Tobin (1958) rather than the OLS. Huang (2011) and Al-Malkawi (2005) have used the Tobit model in the context of dividends. In this regard, we followed Leary and Michaely (2011) by using the Tobit model for dividend smoothing. 
The observed dependent variable (SOA) is given as:

$$
\begin{aligned}
& S O A=\beta_{0}+\beta_{1} \mathrm{X}+\varepsilon_{\text {it }} \\
& \left.\qquad \begin{array}{rl} 
& =0 \text { if } S O A *<0 \\
& =\text { SOA } * \text { if } 0<S O A *<1 \\
& =1 \text { if } S O A *>1
\end{array}\right)
\end{aligned}
$$

where the $\mathrm{SOA}^{*}$ is latent variable, $\mathrm{X}$ represents a vector of explanatory variables, and $\beta_{1}$ represents unknown parameters. $\beta_{0}$ and error term $\left(\varepsilon_{\mathrm{it}}\right)$ are needed to be independent and identically distributed of order $\mathrm{N}\left(0, \sigma^{2} \beta\right)$ and $\mathrm{N}\left(0, \sigma 2 \varepsilon_{\mathrm{it}}\right)$ respectively (Al-Malkawi, Bhatti, \& Magableh, 2014). The Tobit model for the above equation will be estimated through maximum likelihood estimation (MLE). It is worth mentioning that this study will incorporate both banks with $0>\mathrm{SOA}>1$ and $0 \leq \mathrm{SOA} \leq 1$ with the help of the Tobit model which will avoid the selection bias $\rho$ which suggests that addressing the panel level variance is important. Therefore, random-Tobit is preferred over the pooled-Tobit.

We estimated the impact of corporate governance on dividend smoothing via:

$$
\text { SOA }=\beta_{0}+\beta_{1} X+\beta_{2} \text { Duality }+\beta_{3} \text { Bsize }+\beta_{4} \text { Bind }+\beta_{5} \text { Asize }+\varepsilon_{i t}
$$

While the impact of ownership structure on dividend smoothing is estimated via:

$$
S O A=\beta_{0}+\beta_{1} X+\beta_{2} M g t+\beta_{3} \text { Foreign }+\beta_{4} \text { Concentration }+\varepsilon_{i t}
$$

Finally, corporate governance index was developed through the principal component analysis (PCA) and its impact on dividend smoothing was estimated through the following model:

$$
S O A=\beta_{0}+\beta_{1} \mathrm{X}+\beta_{2} \mathrm{CG}-\text { index }+\varepsilon_{i t}
$$

where $\mathrm{X}$ in the above equations is a vector of the control variables chosen from the literature.

\subsection{Variables}

Table 1 depicts the control and independent variables used in the study along with their expected signs and description. 
Table 1: Variables of the Study

\begin{tabular}{|c|c|c|c|}
\hline Variable & Nature & $\begin{array}{l}\text { Expected } \\
\text { relation } \\
\text { with DS }\end{array}$ & Description \\
\hline $\begin{array}{l}\text { Speed of Adjust- } \\
\text { ment (SOA) }\end{array}$ & Dependent & & \\
\hline Risk & Control & $(+)$ & $\begin{array}{l}\text { Standard deviation of EPS over last } \\
\text { five years. }\end{array}$ \\
\hline Size & Control & $(+)$ & Natural logarithm of total assets. \\
\hline Age (History) & Control & $(-)$ & $\begin{array}{l}\text { The number of years listed on the } \\
\text { KSE. }\end{array}$ \\
\hline Growth (MBR) & Control & $(-)$ & $\begin{array}{l}\text { Market value of equity plus book } \\
\text { value of assets minus book value of } \\
\text { equity, all divided by book value of } \\
\text { assets. }\end{array}$ \\
\hline Board Size (Bsize) & Independent & $(+)$ & No. of the directors on the board. \\
\hline $\begin{array}{l}\text { Board Indepen- } \\
\text { dence (Bind) }\end{array}$ & Independent & $(-)$ & $\begin{array}{l}\text { Proportionate no. of non-executive } \\
\text { directors. }\end{array}$ \\
\hline $\begin{array}{l}\text { CEO Duality } \\
\text { (Duality) }\end{array}$ & Independent & $(+)$ & $\begin{array}{l}1 \text { if } \mathrm{CEO} \text { is also chairman of the } \\
\text { board and } 0 \text { otherwise }\end{array}$ \\
\hline $\begin{array}{l}\text { Audit committee } \\
\text { Size (Asize) }\end{array}$ & Independent & $(-)$ & No. of directors in audit committee \\
\hline $\begin{array}{l}\text { Management } \\
\text { Ownership (Mgt) }\end{array}$ & Independent & $(-)$ & $\begin{array}{l}\text { No. of shares held by directors, } \\
\text { their spouses, and children in } \\
\text { proportion to the total outstanding } \\
\text { shares. }\end{array}$ \\
\hline $\begin{array}{l}\text { Foreign Owner- } \\
\text { ship (Foreign) }\end{array}$ & Independent & $(+)$ & $\begin{array}{l}\text { No. of shares held by foreign share- } \\
\text { holders and Pakistani residing } \\
\text { abroad in proportion to the total } \\
\text { outstanding shares. }\end{array}$ \\
\hline
\end{tabular}

\subsection{Principal Component Analysis}

This study aims to estimate the effect of corporate governance in the smoothing of dividends by banks in Pakistan. In this regard, we developed the corporate governance index (CGI) via the principal component analysis. This study uses board size, board independence, 
audit committee size, CEO-duality, management ownership, foreign ownership and shareholders concentration to develop the corporate governance index. The principal component analysis PCA techniques have certain advantages such as enabling firms to incorporate information of the individual bank's corporate governance mechanism to the single index (Agrawal \& Knoeber, 1996). Besides this, the PCA can control for the possible existence of multicollinearity issue among the individual corporate governance variables (Bebchuk \& Cohen, 2005). The PCA also assigns weights to different variables automatically, rather than arbitrarily or similarly.

Two issues were addressed before deciding on the validity of the PCA. One is that the correlations between variables should be higher than that of between errors (sample adequacy) and the other is that the correlation matrix should be factorable i.e., the correlation matrix should be different from the identity matrix (Pett, Lackey, \& Sullivan, 2003). Following Tarchouna, Jarraya and Bouri (2017), this study uses the Kaiser-Meyer-Olkin (KMO) statistic for sample adequacy and Bartlett's test for sphericity.

\section{Results and Discussion}

\subsection{Descriptive Statistics}

Table 2 depicts the characteristics of the dividend-paying and nondividend paying banks. The last two columns report the difference in characteristics between the two sub-samples. Table 2 also reports that non-dividend paying banks were riskier than dividend-paying banks in Pakistan. The difference between the two groups is significant in terms of risk. Similarly, dividend-paying banks were larger in size and have higher growths than non-dividend paying banks. Nonetheless, the ages of both groups were not significantly different. The results are consistent with the agency theory.

Further, Table 2 demonstrates that dividend-paying banks have larger boards and crowded by external directors while the case of nondividend paying banks was otherwise. The difference between the boards of the two groups was statistically significant. However, the difference of the CEO duality and the audit committee size of both groups were not statistically significant.

While the ownership structure of both types of banks as shown in Table 2 depict that dividend-paying banks were controlled by five 
Table 2: Descriptive Statistics

\begin{tabular}{lcrcrrr}
\hline Variables & $\begin{array}{c}\text { Obser- } \\
\text { vations }\end{array}$ & $\begin{array}{c}\text { Payers } \\
(\text { Mean })\end{array}$ & $\begin{array}{c}\text { Non-Payers } \\
\text { (Mean) }\end{array}$ & $\begin{array}{c}\text { Obser- } \\
\text { vations }\end{array}$ & & \\
\hline Risk & 180 & 2.739 & 2.776 & 108 & -1.24779 & 0.0555 \\
Size & 173 & 7.916 & 7.345 & 100 & -.5344483 & 0.0000 \\
History & 103 & 6.485 & 6.145 & 69 & -.3405094 & 0.4707 \\
MBR & 169 & 1.198 & 0.831 & 100 & -.2557195 & 0.0768 \\
EPS & 179 & 5.328 & -0.445 & 106 & -6.124338 & 0.0000 \\
Bsize & 142 & 8.451 & 7.859 & 99 & -.5851228 & 0.0016 \\
Bind & 138 & 76.76 & 6.313 & 99 & 2.944015 & 0.0802 \\
Duality & 141 & 0.0496 & 0.0300 & 100 & -.0166667 & 0.5120 \\
Asize & 143 & 3.294 & 3.350 & 100 & .0736842 & 0.3644 \\
Mgt & 140 & 8.583 & 8.428 & 99 & -.5166613 & 0.7620 \\
Concentration & 119 & 72.47 & 66.76 & 95 & -5.291362 & 0.0215 \\
Foreign & 115 & 15.52 & 2.171 & 93 & -13.2192 & 0.0000 \\
\hline
\end{tabular}

largest shareholders who own 72 per cent shares, the difference between the two groups was statistically significant regarding the concentration. This might be signaling the type II agency problem. Moreover, foreigners prefer dividend-paying banks rather than non-dividend banks; hence this finding is consistent with the rent hypothesis. From the two types of banks, we further grouped the dividend paying banks into two sub-groups based on the dividend smoothing perspective. Banks having the speed of adjustment (SOA) greater than the sample mean value were termed as non-smoothing and banks having the SOA of less than the sample mean value were in the other group.

Table 3 illustrates that banks involved in smoothing were riskier, larger in size, high growing and relatively new. These results were grounded both in the agency and information asymmetry theory. Besides this, dividend smoothing banks were shown to be having statistically larger earnings (depicted by both the EBIT and EPS). Similarly, dividend smoothing banks were paying statistically higher dividends (on average Pak Rs.3.26 against Rs.2.02 for non-smoothers).

Table 3 reports that banks involved in higher dividend smoothing were having larger boards and less crowded by outside directors. This supports $\mathrm{H}_{1}$ and $\mathrm{H}_{2}$ of the study. The results are in line with the agency theory. Interestingly, all the dividend smoothing banks in the sample 
Table 3: Smoothing vs Non-smoothing Banks

\begin{tabular}{|c|c|c|c|c|c|c|}
\hline \multirow[t]{2}{*}{ Variables } & \multicolumn{2}{|c|}{ Observations } & \multicolumn{2}{|c|}{ Mean } & \multirow[t]{2}{*}{ Coefficients } & \multirow[t]{2}{*}{$\mathrm{p}$-value } \\
\hline & Smooth & $\begin{array}{l}\text { Non- } \\
\text { Smooth }\end{array}$ & Smooth & $\begin{array}{l}\text { Non- } \\
\text { Smooth }\end{array}$ & & \\
\hline Risk & 99 & 81 & 2.846377 & 2.60811 & .2382668 & 0.4827 \\
\hline Size & 92 & 81 & 8.036103 & 7.780549 & .2555543 & 0.0992 \\
\hline History & 58 & 45 & 6.241379 & 6.8 & -.5586207 & 0.3613 \\
\hline MBR & 91 & 78 & 1.497717 & .8477504 & .6499662 & 0.0000 \\
\hline EBIT & 99 & 81 & 9273667 & 4763766 & 4509901 & 0.0044 \\
\hline DPS & 92 & 81 & 3.262626 & 2.029938 & 1.232688 & 0.0150 \\
\hline EPS & 91 & 78 & 6.165657 & 4.291627 & 1.87403 & 0.0824 \\
\hline Bsize & 89 & 53 & 8.640449 & 8.132075 & .508374 & 0.0908 \\
\hline Bind & 89 & 49 & 76.53159 & 77.16502 & -.6334313 & 0.8094 \\
\hline Asize & 90 & 53 & 3.377778 & 3.150943 & .2268344 & 0.0574 \\
\hline Duality & 88 & 53 & 0 & .1320755 & -.1320755 & 0.0004 \\
\hline Concentration & 74 & 45 & 77.06428 & 64.90292 & 12.16137 & 0.0005 \\
\hline Mgt & 87 & 53 & 7.129304 & 10.96836 & -3.839054 & 0.0853 \\
\hline Foreign & 77 & 38 & 19.14938 & 8.168897 & 10.98048 & 0.0449 \\
\hline
\end{tabular}

were free from the CEO duality. By looking at the ownership statistics in the above table, it was observed that banks with a higher degree of dividend smoothing were having low management ownership and were more controlled by five largest shareholders. These results were consistent with the agency and information asymmetry theories. Similarly, Table 3 also reports that foreign investors prefer banks offering smooth dividends. All these ownership statistics affirm our hypothesis.

\subsection{Dividend Smoothing: Cross-sectional Regressions}

We used the random Tobit technique to estimate the impact of governance on dividend smoothing banks, both in Table 4 and Table 6 . The likelihood ratio test reported that the pooled Tobit was significantly different at the 1 per cent level from the random-Tobit. Therefore, the panel level variance could not be ignored. Details of all the likelihood ratio tests were not reported for the purpose of brevity. Table 4 depicts the results of the random Tobit estimated through maximum likelihood 
estimation (MLE). The seven columns in Table 4 depict the impact of each independent variable on dividend smoothing, along with the controls which include risk, size, age and growth of the banks.

Column 1 of Table 4 depicts that banks having volatile earnings and are large in size opted for more dividend smoothing. Our results were parallel to Leary and Michaely (2011). These results were supported by the agency based explanation of dividend smoothing because such firms were exposed to higher levels of the agency problem. Parallel to the findings of Javakhadze et al. (2014), this column also reports that old and fast growing (measured by the market to book ratio) Pakistani banks, opted for a lower level dividend smoothing. Column 1 reports that large boards result in higher levels of dividend smoothing, thereby supporting $\mathrm{H}_{1}$ of the study which states that large boards have coordination problems and are not good monitors. This positive association of board size and dividend smoothing is parallel to the results of La Porta et al. (2000).

Column 2 of Table 4 shows that banks with independent boards opt for a low level of dividend smoothing. Increasing board independence by a unit will cause a 0.25 per cent reduction in dividend smoothing. This affirms that dividend smoothing is an alternative mechanism of monitoring, thereby supporting $\mathrm{H}_{2}$ of the study. The negative association of board independence and dividend smoothing was also witnessed by Javakhadze et al. (2014).

Consistent with $\mathrm{H}_{3}$ of the study and in line with Raheja (2005), Column 3 of Table 4 depicts that an increase in audit committee size of the banks lowers the demand for dividend smoothing. $\mathrm{H}_{3}$ was based on the notion that increasing the size of the audit committee directly increases the number of independent directors on the committee as the SECP had banned executive directors, CEOs or chairpersons from being on the audit committee in Pakistan.

Column 4 of Table 4 depicts interesting results; it shows that banks with CEO-duality opted for a low level of dividend smoothing. This result was not consistent with $\mathrm{H}_{4}$ of the study. It supported the stewardship view which states that CEOs in Pakistani banks might not have willingly availed the joint position but were given the positions due to the persons being the most well informed and visionary one in the bank. This result is parallel to the findings of Zhang (2008).

Column 5 of Table 4 shows that banks with more management ownership practiced lower level dividend smoothing which is consistent with the agency based explanation of dividend smoothing. As banks with more management ownership have greater alignment, and face a 


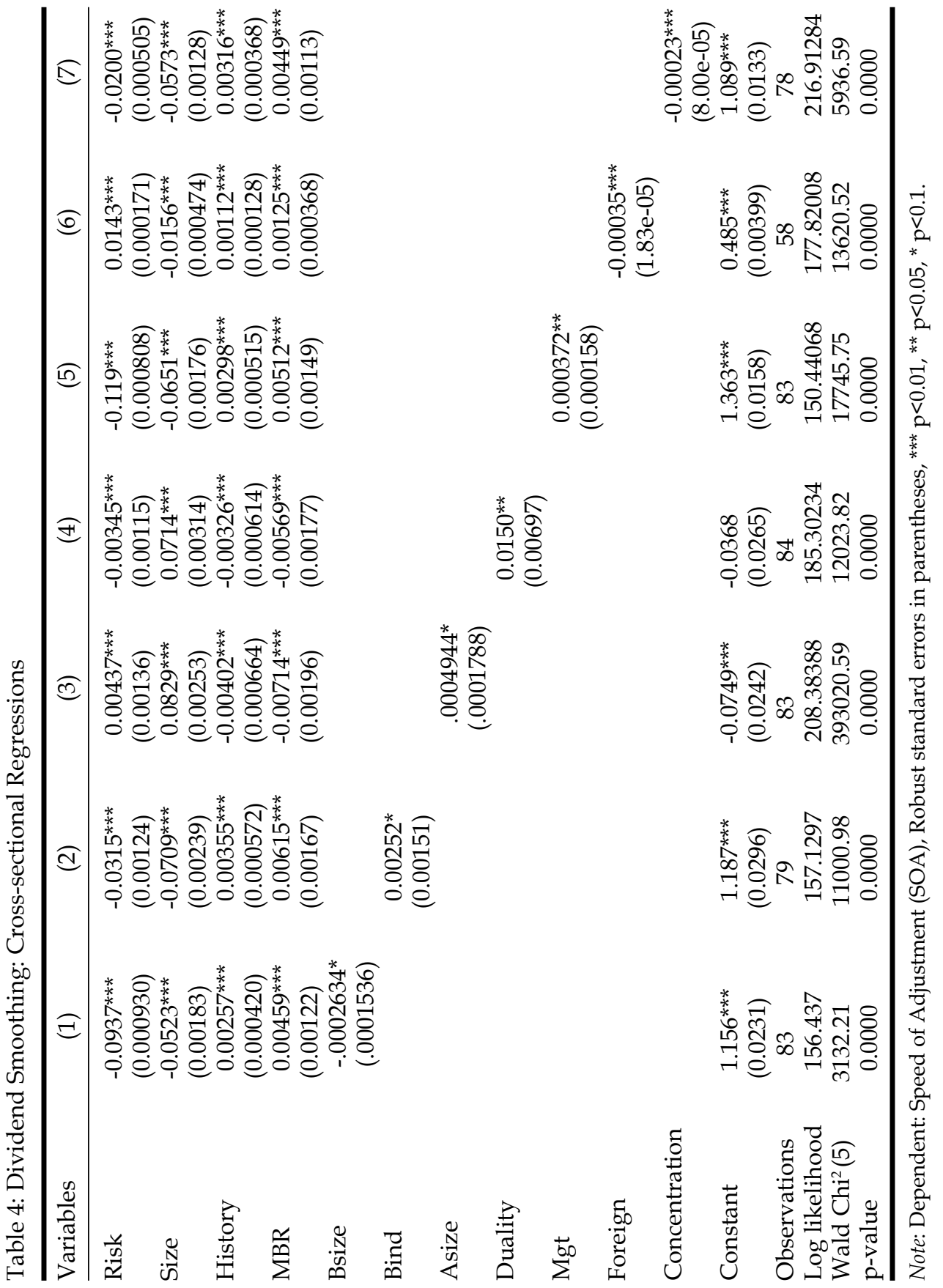


lower level of agency risk, they were thus likely to ask for a lower level of dividend smoothing. These results were consistent with the outcome generated by Farinha (2003).

Column 6 of Table 4 also shows that companies with more foreign ownership opted for a higher level of dividend smoothing which is consistent with the rent hypothesis of dividends. The last column of Table 4 shows that banks with a higher level of ownership concentration opted for higher dividend smoothing, which is consistent with $\mathrm{H}_{7}$ of the study. Banks with a higher level of ownership concentration were exposed to low level type-I agency problems but to a higher level of type-II agency problems. This result of the study is consistent with the expropriation hypothesis and also consistent with the findings of Jeong (2011).

The overall outcome drawn from Table 4 suggests that banks with good corporate governance choose a low level of dividend smoothing. In other words, banks with small independent boards, large audit committees, and having a joint position of CEO and chairperson, tend to choose a low level of dividend smoothing. Similarly, banks with a low proportion of management and higher level foreign ownership go for a higher degree of dividend smoothing. Finally, banks with high ownership concentration were involved in a higher level of dividend smoothing. These results were also comparable to the findings of Leary and Michaely (2011) and Javakhadze et al. (2014).

\subsection{Corporate Governance Index}

Our study used the principal component analysis (PCA) for developing the corporate governance index (CGI). The main purpose of the PCA was to reduce the number of variables into uncorrelated components. The first component of the PCA incorporated the largest variance of the data. Following Tarchouna et al. (2017), we also chose the first factor which represents the largest variation of board size, board independence, audit size, CEO-duality, management, foreign and majority ownership in Pakistani banks between 2006 to 2014. The PCA combined these seven variables into a linear combination which we have termed as corporate governance index.

Table 5 depicts the weights of all the seven corporate governance variables used in the corporate governance index for Pakistani banks during the sample period. Table 5 demonstrates that both board size and board independence have a positive contribution to the corporate governance index. This indicates that large boards crowded by indepen- 
Table 5: Weights of the Corporate Governance Index

\begin{tabular}{lc}
\hline Variables & Corporate \\
\hline Board size & 0.852 \\
Board independence & 0.493 \\
Audit size & 0.670 \\
CEO-Duality & -0.304 \\
Mgt & 0.178 \\
Foreign & -0.248 \\
Concentration & -0.686 \\
Kaiser-Meyer-Olkin Statistic & 0.576 \\
Bartlett's test p-value & 0.000 \\
\hline
\end{tabular}

dent directors have good monitoring power. Such banks exhibit good corporate governance. Similarly, it can be noticed that audit committee has a positive contribution to corporate governance. This is in line with our notion that increasing audit committee size automatically increases the number of independent members on the committee in Pakistan, in light of the rules developed by the SBP and the SECP. Banks with large audit committees reflect good corporate governance (Raheja, 2005).

Likewise, the contribution of the CEO-duality to corporate governance was negative which state that banks with CEO-duality in a family-controlled firm will affect the monitoring power of the board. Similarly, management ownership has a positive contribution to the corporate governance. This is in line with the notion that banks with high ownership have greater alignment. It was also observed that foreign ownership contributes negatively and this may be due to the fact that foreigners were more interested in the rent extraction, thereby avoiding good corporate governance. The contribution of the ownership concentration to corporate governance index was large and negative. This is in line with the notion that the higher the control of major shareholders, the higher the chances of expropriation.

\subsection{Final Results}

Table 6 shows our main results with the speed of adjustment (SOA) as the dependent variable, estimated through equation (1). We employed random Tobit techniques to account for the panel-level variance 
component. As the results of the likelihood ratio test recommended, the pooled Tobit results were significantly different from the random-Tobit results. Across all the regressions of Table 6, we have controlled for size, age, earnings volatility and firms' growth. The results noted in Table 6 support the hypotheses of this study. By including board and ownership structure in the above regressions, it was noted that all variables have predicted signs at a significant level, except for the CEO-duality.

The first column of Table 6 is in line with $\mathrm{H}_{1}$, board size has a negative and significant coefficient. Banks with large board size smooth dividends more. This result is consistent with our conjecture that large boards have coordination problems and are not good monitors until crowded by the independent directors. Our result is consistent with La Porta et al. (2000). Column 1 in Table 6 also shows that banks with a high proportion of independent directors smooth less. This supports $\mathrm{H}_{2}$. This result is according to our conjecture which observed that banks with independent boards would be exposed to low level agency problems, therefore, they would opt for less smooth dividends. Our results were parallel to the findings of Krishna Prasanna (2014) and Ghosh and Sirmans (2006). Similar to Raheja (2005), the results in Table 6 indicates that banks with large audit committees smooth dividends less. Large audit committees were expected to have many independent directors which then reduce the level of agency conflict and information asymmetry. Consequently, such firms exhibit a lower level of dividend smoothing.

Interestingly our result for the CEO duality was contrary to $\mathrm{H}_{4}$ of the study. In line with the stewardship view, we found that banks having a joint position of CEO and chairperson smooth less, hence CEOs might not have availed the joint position unless he/she is the most informed person in the bank. This result is parallel to the findings of Zhang (2008). It is an interesting result in the article, as the information asymmetry caused by the CEO duality was not substituted by smooth dividends but instead, exhibited support for the stewardship view.

In column 2 of Table 6, we estimated the relationship between ownership structure and dividend smoothing. In line with the study of Boumosleh and Cline (2015), Table 6 shows that Pakistani banks with high management ownership smooth less because of greater alignment, caused by high management ownership. Banks with low insider ownership have severe agency problems, hence they smooth more. Consistent with the rental hypothesis and in line with the outcome of Baba (2009), Table 6 depicts that banks with a high proportion of foreign ownership opted for more dividend smoothing. Consistent to $\mathrm{H}_{7}$, we 
Table 6: Panel Tobit Regression: Role of Corporate Governance in Dividend Smoothing

\begin{tabular}{|c|c|c|c|}
\hline Variables & $\begin{array}{c}(1) \\
\text { Board }\end{array}$ & $\begin{array}{c}(2) \\
\text { Ownership }\end{array}$ & $\begin{array}{c}(3) \\
\text { CG-Index }\end{array}$ \\
\hline Risk & $\begin{array}{l}-0.0707^{* * *} \\
(0.0247)\end{array}$ & $\begin{array}{c}0.0679 * * * \\
(0.00611)\end{array}$ & $\begin{array}{c}0.0684^{* * *} \\
(0.00921)\end{array}$ \\
\hline Size & $\begin{array}{l}-0.172^{* * *} \\
(0.0581)\end{array}$ & $\begin{array}{l}-0.0327 \\
(0.0212)\end{array}$ & $\begin{array}{l}0.0690^{* *} \\
(0.0316)\end{array}$ \\
\hline History & $\begin{array}{l}-0.00242 \\
(0.0145)\end{array}$ & $\begin{array}{c}0.00853 \\
(0.00841)\end{array}$ & $\begin{array}{l}-0.0138 \\
(0.0103)\end{array}$ \\
\hline MBR & $\begin{array}{l}-0.0873^{*} \\
(0.0466)\end{array}$ & $\begin{array}{l}-0.0497^{* *} \\
(0.0198)\end{array}$ & $\begin{array}{l}-0.0786^{* *} \\
(0.0314)\end{array}$ \\
\hline Board size & $\begin{array}{l}-0.161^{* *} \\
(0.0642)\end{array}$ & & \\
\hline Board independence & $\begin{array}{c}0.110^{* *} \\
(0.0506)\end{array}$ & & \\
\hline Audit size & $\begin{array}{c}0.174^{*} \\
(0.0920)\end{array}$ & & \\
\hline CEO-Duality & $\begin{array}{l}0.302^{* *} \\
(0.123)\end{array}$ & & \\
\hline Mgt & & $\begin{array}{c}0.00673^{* * *} \\
(0.000805)\end{array}$ & \\
\hline Foreign & & $\begin{array}{l}-0.00837^{* * *} \\
(0.00137)\end{array}$ & \\
\hline Concentration & & $\begin{array}{l}-0.0158^{* * *} \\
(0.00416)\end{array}$ & \\
\hline CG-Index & & & $\begin{array}{c}0.148^{* * *} \\
(0.0345)\end{array}$ \\
\hline Constant & $\begin{array}{l}2.307^{* * *} \\
(0.600)\end{array}$ & $\begin{array}{l}1.766^{* * *} \\
(0.431)\end{array}$ & $\begin{array}{l}-0.197 \\
(0.234)\end{array}$ \\
\hline Observations & 79 & 57 & 57 \\
\hline Log likelihood & 170.08003 & 96950.83 & 61636.26 \\
\hline Wald $\mathrm{Chi}^{2}(5)$ & 17382.04 & 178.60845 & 173.60339 \\
\hline$p$-value & 0.0000 & 0.0000 & 0.0000 \\
\hline
\end{tabular}

Note: Dependent: Speed of Adjustment (SOA), Robust standard errors in parentheses, $* * *=p<0.01,{ }^{* *}=p<0.05, *=p<0.1$. 
found that banks with concentrated ownership smooth more. This is because concentrated banks have low level type I but high level type II agency problems. In this respect, concentrated banks used dividend smoothing as an alternative monitoring mechanism. This result is in line with the findings of Shleifer and Vishny (1997) which showed that high agency conflict exists between controlling and minority shareholders. Therefore, this positive association of dividend smoothing and ownership concentration could be due to type II agency problem or it could be an effort to dilute the impression of the expropriation of minority shareholders.

In the last column of Table 6, we regressed the speed of adjustment (SOA) with corporate governance index developed via the PCA by incorporating board size, board independence, audit committee size, management, foreign ownership and five largest shareholders. We found a negative association of the corporate governance index with dividend smoothing. This is in tandem with the substitution hypothesis which states that in weak corporate governance environment, dividend smoothing is an alternative monitoring mechanism. This result is parallel to those of Leary and Michaely (2011) and Javakhadze et al. (2014).

\section{Conclusion and Implications}

This study has examined the impact of corporate governance on dividend smoothing in 19 listed Pakistani banks for the period ranging between 2006 and 2014. The study found evidence of dividend smoothing in Pakistani banks by using Lintner's (1956) approach. The study addressed elements which could impact the degree of dividend smoothing in these banks which encompass board size, board independence, audit committee size, CEO-duality, management, foreign ownership and five largest shareholders. Unlike developed economies, Pakistan is a country known for its weak shareholders' rights and weak corporate governance. Firm ownership structure in Pakistani corporations is mostly characterised by the family-controlled structure. In this scenario, dividend smoothing becomes an alternative monitoring mechanism to good corporate governance.

This study offers evidence which show that small boards crowded by outside directors have a strong monitoring power. Pakistani banks with large boards crowded by inside directors tend to opt for a higher level of dividend smoothing. Banks with large audit committees go for the lower level of dividend smoothing. Interestingly, banks with CEO 
duality were involved in lower level of dividend smoothing which is in line with the stewardship view. Banks with a higher level of ownership consisting of directors and their spouses were involved in less dividend smoothing as a result of greater alignment. We also found that banks with higher foreign ownership opted for higher level of dividend smoothing while we noticed that foreign shareholders demanded large and stable dividends in accordance with the rent hypothesis. Our study also found that banks with concentration ownership paid smooth dividends in order to reduce type-II agency problems, i.e., to reduce chances of expropriation by major shareholders. After constituting the corporate governance index through the PCA based on the seven corporate governance variables, we found that dividend smoothing substitutes as corporate governance, as exhibited by the Pakistani banks.

Our study has contributed to the dividend smoothing literature in several ways. First, our study is the first dividend smoothing study conducted in a developing country like Pakistan. Second, to the best of our knowledge, it is the first dividend smoothing study related to banks. Third, our study is the first of its kind which estimated the effects of individual corporate governance mechanism on dividend smoothing. Our study found that corporate governance and dividend smoothing played a substitution role in the listed banks of Pakistan. In other words, stable and increasing dividends are the alternative monitoring mechanism for shareholders. Higher information asymmetry in banks, high regulatory requirements, low shareholders rights and weak corporate governance environment make dividend smoothing another tool for safeguarding minority shareholders in Pakistani listed banks. The SBP and SECP have been focusing only on corporate governance mechanisms for protecting shareholders. Nonetheless, our study concludes that committing banks to the smooth dividends will help to safeguard minority shareholders' interest from expropriation.

Our study found that banks with CEO duality smoothed less; therefore, future research could investigate the impact of CEO characteristics on dividend smoothing. Our study found concentrated firms to smooth more as a measure to counter type II agency problems. This may be further investigated by looking at the moderating role of type II agency problem in the same context. Since our study was based on a small sample, its findings may not be generalised to the whole of Pakistan. Therefore, the results may be empirically investigated by focusing on larger samples of data. 


\section{References}

Agrawal, A., \& Knoeber, C.R. (1996). Firm performance and mechanisms to control agency problems between managers and shareholders. Journal of Financial and Quantitative Analysis 31(3), 377-397. http://dx.doi.org/ $10.2307 / 2331397$

Al-Kuwari, D. (2009). Determinants of the dividend policy of companies listed on emerging stock exchanges: The case of the Gulf Cooperation Council (GCC) Countries. Global Economy \& Finance Journal, 2(2), 38-63.

Al-Malkawi, H.-A.N. (2007). Determinants of corporate dividend policy in Jordan: An application of the Tobit model. Journal of Economic and Administrative Sciences, 23(2), 44-70. http:// dx.doi.org/10.1108/10264116200700007

Al-Malkawi, H.-A.N., Bhatti, M.I., \& Magableh, S.I. (2014). On the dividend smoothing, signaling and the global financial crisis. Economic Modelling 42(October), 159-165. http:// dx.doi.org/10.1016/j.econmod.2014.06.007

Al-Malkawi, H.-A.N.Y. (2005). Dividend policy of publicly quoted companies in emerging markets: The case of Jordan (Doctoral thesis, University of Western Sydney, Australia). Retrieved from https://researchdirect.westernsydney. edu.au/islandora/object/uws:819

Allen, F., Bernardo, A.E., \& Welch, I. (2000). A theory of dividends based on tax clienteles. The Journal of Finance, 55(6), 2499-2536. http://dx.doi.org/ 10.1111/0022-1082.00298

Armstrong, C.S., Core, J.E., \& Guay, W.R. (2014). Do independent directors cause improvements in firm transparency? Journal of Financial Economics 113(3), 383-403. http://dx.doi.org/10.1016/j.jfineco.2014.05.009

Baba, N. (2009). Increased presence of foreign investors and dividend policy of Japanese firms. Pacific-Basin Finance Journal 17(2), 163-174. http://dx.doi. org/10.1016/j.pacfin.2008.04.001

Baker, H.K., \& Kapoor, S. (2015). Dividend policy in India: New survey evidence. Managerial Finance, 41(2), 182-204. http://dx.doi.org/10.1108/ MF-01-2014-0024

Bebchuk, L.A., \& Cohen, A. (2005). The costs of entrenched boards. Journal of Financial Economics 78(2), 409-433. http://dx.doi.org/10.1016/j.jfineco.2004. 12.006

Bebchuk, L.A., \& Weisbach, M.S. (2010). The state of corporate governance research. The Review of Financial Studies, 23(3), 939-961. http://dx.doi. org/10.1093/rfs/hhp121

Bebczuk, R.N. (2005). Corporate governance and ownership: Measurement and impact on corporate performance and dividend policies in Argentina. Retrieved from http://sedici.unlp.edu.ar/handle/10915/3547

Boumosleh, A., \& Cline, B.N. (2015). Outside director stock options and dividend policy. Journal of Financial Services Research 47(3), 381-410. http:/ / dx.doi.org/10.1007/s10693-013-0174-2 
Brav, A., Graham, J.R., Harvey, C.R., \& Michaely, R. (2005). Payout policy in the 21st century. Journal of Financial Economics, 77(3), 483-527. http://dx.doi. org/10.1016/j.jfineco.2004.07.004

DeMarzo, P.M., \& Sannikov, Y. (2008). Learning in dynamic incentive contracts. Retrieved from https://pdfs.semanticscholar.org/d8e8/d2cf822f78747d5c 5c84bfddc7eed75a699f.pdf

Easterbrook, F.H. (1984). Two agency-cost explanations of dividends. The American Economic Review 74(4), 650-659.

Fama, E.F., \& Babiak, H. (1968). Dividend policy: An empirical analysis. Journal of the American Statistical Association 63(324), 1132-1161. http://dx.doi.org/1 0.1080/01621459.1968.10480917\#.W_TW7kxuLIU

Fama, E.F., \& Jensen, M.C. (1983). Separation of ownership and control. The Journal of Law and Economics, 26(2), 301-325. http://dx.doi.org/10.1086/ 467037

Farinha, J. (2003). Dividend policy, corporate governance and the managerial entrenchment hypothesis: An empirical analysis. Journal of Business Finance and Accounting, 30(9-10), 1173-1209. http://dx.doi.org/10.1111/j.0306686X.2003.05624.x

Fatima, S. (2016). Corporate governance in Pakistan: Beyond a minimalist approach (Doctoral thesis, University of Bedfordshire, UK). Retrieved from http:// uobrep.openrepository.com/uobrep/handle/10547/621843

Florackis, C., Kanas, A., \& Kostakis, A.l. (2015). Dividend policy, managerial ownership and debt financing: A non-parametric perspective. European Journal of Operational Research, 241(3), 783-795. http://dx.doi.org/10.1016/ j.ejor.2014.08.031

Fudenberg, D., \& Tirole, J. (1995). A theory of income and dividend smoothing based on incumbency rents. Journal of Political Economy, 103(1), 75-93. http://dx.doi.org/10.1086/261976

Ghosh, C., \& Sirmans, C.F. (2006). Do managerial motives impact dividend decisions in REITs? The Journal of Real Estate Finance and Economics, 32(3), 327-355. http://dx.doi.org/10.1007/s11146-006-6805-8

Gordon, M.J. (1963). Optimal investment and financing policy. The Journal of Finance 18(2), 264-272. http://dx.doi.org/10.1111/j.1540-6261.1963. tb00722.x

Haque, D.A., Jalil, M.B., \& Naz, F. (2007). State of corporate governance in Bangladesh: Analysis of public limited companies - financial, non-financial institutions and state owned enterprises. Retrieved from http://dspace. ewubd.edu/handle/123456789/410

Hermalin, B.E. (2005). Trends in corporate governance. The Journal of Finance 60(5), 2351-2384. http://dx.doi.org/10.1111/j.1540-6261.2005.00801.x

Huang, H.-C.R. (2011). Bayesian analysis of the dividend behaviour. Applied Financial Economics 11(3), 333-339. http://dx.doi.org/10.1080/ 096031001300138735 
Hussain, E., \& Shah, A. (2015). Impact of ownership structure on dividend smoothing: A comparison of family and non-family firms in Pakistan. Afro-Asian Journal of Finance and Accounting, 5(4), 356-377. http://dx.doi. org/10.1504/ AAJFA.2015.073489

Institute of Cost and Management Accountants of Pakistan (2011). Shareholding pattern of corporate sector in Pakistan - An insight on dominance business groups and families over corporate ownership structure. Retrieved from https://www. icmap.com.pk/News_Pdf/Pattern_shareholding.pdf

IFC (2016). Corporate governance. Washington, D.C.: Author.

Iqbal, S. (2013). The impact of corporate governance on dividend decision of firms: Evidence from Pakistan. African Journal of Business Management, 7(11), 811-817.

Javakhadze, D., Ferris, S.P., \& Sen, N. (2014). An international analysis of dividend smoothing. Journal of Corporate Finance 29(December), 200-220. http://dx.doi.org/10.1016/j.jcorpfin.2014.09.007

Jensen, M.C. (1986). Agency costs of free cash flow, corporate finance, and takeovers. The American Economic Review, 76(2), 323-329.

Jensen, M.C. (1993). The modern industrial revolution, exit, and the failure of internal control systems. The Journal of Finance 48(3), 831-880. http:/ / dx.doi. org/10.1111/j.1540-6261.1993.tb04022.x

Jensen, M.C., \& Meckling, W.H. (1976). Theory of the firm: Managerial behavior, agency costs and ownership structure. Journal of Financial Economics 3(4), 305-360. http://dx.doi.org/10.1016/0304-405X(76)90026-X

Jeong, J. (2011). An investigation of dynamic dividend behavior in Korea. The International Business \& Economics Research Journal 10(6), 21-32. http:// dx.doi.org/10.19030/iber.v10i6.4370

Jeong, J. (2013). Determinants of dividend smoothing in emerging market: The case of Korea. Emerging Markets Review 17(December), 76-88. http:/ / dx.doi. org/10.1016/j.ememar.2013.08.007

Kowalewski, O., Stetsyuk, I., \& Talavera, O. (2007). Corporate governance and dividend policy in Poland (Wharton Financial Institutions Center, Working Paper No. 07-09). Retrieved from https:/ / ssrn.com/abstract=986111

Krishna Prasanna, P. (2014). Firm-level governance quality and dividend decisions: Evidence from India. International Journal of Corporate Governance 5(3/4), 197-222. http://dx.doi.org/10.1504/IJCG.2014.064726

La Porta, R., Lopez-de-Silanes, F., Shleifer, A., \& Vishny, R.W. (2000). Agency problems and dividend policies around the world. The Journal of Finance, 55(1), 1-33. http:// dx.doi.org/10.1111/0022-1082.00199

Lambrecht, B.M., \& Myers, S.C. (2010). A Litner model of payout and managerial rents. The Journal of Finance, 67(5), 1761-1810. http://dx.doi. org/10.1111/j.1540-6261.2012.01772.x

Lazarides, T., Drimpetas, E., \& Dimitrios, K. (2009). Ownership structure in Greece: Impact of corporate governance. IUP Journal of Corporate Governance $8(3 / 4), 75-90$. 
Leary, M.T., \& Michaely, R. (2011). Determinants of dividend smoothing: Empirical evidence. The Review of Financial Studies, 24(10), 3197-3249. http:// dx.doi.org/10.1093/rfs/hhr072

Lee, W.J. (2011). Managerial entrenchment and the value of dividends. Review of Quantitative Finance and Accounting, 36(2), 297-322. http://dx.doi. org/10.1007/s11156-010-0179-y

Lehn, K.M., Patro, S., \& Zhao, M. (2009). Determinants of the size and composition of US corporate boards: 1935-2000. Financial Management, 38(4), 747-780. http://dx.doi.org/10.1111/j.1755-053X.2009.01055.x

Liljeblom, E., \& Maury, B. (2016). Shareholder protection, ownership, and dividends: Russian evidence. Emerging Markets Finance and Trade, 52(10), 2414-2433. http://dx.doi.org/10.1080/1540496X.2015.1073991

Lintner, J. (1956). Distribution of incomes of corporations among dividends, retained earnings, and taxes. The American Economic Review, 46(2), 97-113.

Litzenberger, R.H., \& Ramaswamy, K. (1982). The effects of dividends on common stock prices tax effects or information effects? The Journal of Finance, 37(2), 429-443. http://dx.doi.org/10.1111/j.1540-6261.1982.tb03565.x

Maury, C.B., \& Pajuste, A. (2002). Controlling shareholders, agency problems, and dividend policy in Finland. LTA 1(2), 15-45.

McGuinness, P.B., Lam, K.C., \& Vieito, J.P. (2015). Gender and other major board characteristics in China: Explaining corporate dividend policy and governance. Asia Pacific Journal of Management 32(4), 989-1038. http:// dx.doi.org/10.1007/s10490-015-9443-y

McMullen, D.A. (1996). Audit committee performance: An investigation of the consequences associated with audit committees. Auditing 15(1), 87-96.

Michaely, R., \& Roberts, M.R. (2011). Corporate dividend policies: Lessons from private firms. The Review of Financial Studies, 25(3), 711-746. http://dx.doi. org/10.1093/rfs/hhr108

Peng, M.W., Zhang, S., \& Li, X. (2007). CEO duality and firm performance during China's institutional transitions. Management and Organization Review, 3(2), 205-225. http://dx.doi.org/10.1111/j.1740-8784.2007.00069.x

Petra, S. (2002). The effects of governance structure and ownership structure on the informativeness of earnings (Doctoral thesis, The State University of New Jersey).

Pett, M.A., Lackey, N.R., \& Sullivan, J.J. (2003). Making sense of factor analysis: The use of factor analysis for instrument development in health care research. Thousand Oaks, CA: Sage Publications.

Raheja, C.G. (2005). Determinants of board size and composition: A theory of corporate boards. Journal of Financial and Quantitative Analysis, 40(2), 283306. http://dx.doi.org/10.1017/S0022109000002313

Reaz, M., \& Arun, T. (2006). Corporate governance in developing economies: Perspective from the banking sector in Bangladesh. Journal of Banking Regulation 7(1-2), 94-105. http://dx.doi.org/10.1057/palgrave.jbr.2340007 
Rehman, R., Hasan, M., Mangla, I.U., \& Sultana, N. (2012). Economic reforms, corporate governance and dividend policy in sectoral economic growth in Pakistan. The Pakistan Development Review, 51(4), 133-145.

Rodriguez-Dominguez, L., Gallego-Alvarez, I., Garcia-Sanchez, I.M. (2009). Corporate governance and codes of ethics. Journal of Business Ethics, 90(2), 187-202. http://dx.doi.org/10.1007/s10551-009-0035-y

Sawicki, J. (2009). Corporate governance and dividend policy in Southeast Asia pre- and post-crisis. The European Journal of Finance 15(2), 211-230. http:// dx.doi.org/10.1080/13518470802604440

SBP. (2006). Banking system review. Islamabad: State Bank of Pakistan.

SECP. (2013). Public sector companies corporate governance compliance guidelines, 2013. Retrieved from http://www.secp.gov.pk/notification/pdf/2013/

Setia-Atmaja, L., Tanewski, G.A., \& Skully, M. (2009). The role of dividends, debt and board structure in the governance of family controlled firms. Journal of Business Finance \& Accounting, 36(7-8), 863-898. http://dx.doi. org/10.1111/j.1468-5957.2009.02151.x

Sharif, M., \& Rashid, K. (2014). Corporate governance and corporate social responsibility (CSR) reporting: An empirical evidence from commercial banks (CB) of Pakistan. Quality \& Quantity, 48(5), 2501-2521. http://dx.doi. org/10.1007/s11135-013-9903-8

Sharma, V. (2011). Independent directors and the propensity to pay dividends. Journal of Corporate Finance, 17(4), 1001-1015. http://dx.doi.org/10.1016/ j.jcorpfin.2011.05.003

Shleifer, A., \& Vishny, R.W. (1986). Large shareholders and corporate control. Journal of Political Economy, 94(3, Part 1), 461-488.

Shleifer, A., \& Vishny, R.W. (1997). A survey of corporate governance. The Journal of Finance 52(2), 737-783. http://dx.doi.org/10.1111/j.1540-6261. 1997.tb04820.x

Tarchouna, A., Jarraya, B., \& Bouri, A. (2017). How to explain non-performing loans by many corporate governance variables simultaneously? A corporate governance index is built to US commercial banks. Research in International Business and Finance 42(December), 645-657. http://dx.doi. org/10.1016/j.ribaf.2017.07.008

Tobin, J. (1958). Estimation of relationships for limited dependent variables. Econometrica: Journal of the Econometric Society, 26(1), 24-36. http://dx.doi. org/10.2307/1907382

Ur Rehman, R., \& Mangla, I.U. (2010). Corporate governance and performance of financial institutions in Pakistan: A comparison between conventional and Islamic banks in Pakistan. The Pakistan Development Review, 49(4), 461-475.

Wardhana, L., Tandelilin, E., Wayan Nuka Lantara, I., \& Junarsin, E. (2014). Dividend policy in Indonesia: A life-cycle explanation. Paper presented at the Asian Finance Association (AsianFA) 2014 Conference, Indonesia. Retrieved 
from https://ssrn.com/abstract=2396267 or http://dx.doi.org/10.2139/ ssrn.2396267

Yermack, D. (1996). Higher market valuation of companies with a small board of directors. Journal of Financial Economics, 40(2), 185-211. http://dx.doi. org/10.1016/0304-405X(95)00844-5

Zhang, H. (2008). Corporate governance and dividend policy: A comparison of Chinese firms listed in Hong Kong and in the Mainland. China Economic Review 19(3), 437-459. http:/ / dx.doi.org/10.1016/j.chieco.2008.01.001 
Appendix

\begin{tabular}{|c|c|c|c|c|c|c|c|}
\hline Name of Bank & DPS & BSize & Bindep & Asize & $\begin{array}{l}\text { Mgt__ } \\
\text { Own }\end{array}$ & $\begin{array}{l}\text { Foreign_ } \\
\text { Own }\end{array}$ & Own_Con \\
\hline $\begin{array}{l}\text { Habib Bank } \\
\text { Limited }\end{array}$ & 6.17 & 7.67 & 39.29 & 3.5 & 0.11 & 0.48 & 94.53 \\
\hline $\begin{array}{c}\text { National Bank } \\
\text { of Pakistan }\end{array}$ & 6.11 & 6.33 & 83.85 & 3.4 & 0.008 & 7.13 & 82.85 \\
\hline $\begin{array}{l}\text { United Bank } \\
\text { Limited }\end{array}$ & 5.89 & 8 & 84.01 & 2.86 & 9.99 & 57.93 & 72.22 \\
\hline $\begin{array}{c}\text { MCB Bank } \\
\text { Limited }\end{array}$ & 11.9 & 11.89 & 91.47 & 4.67 & 9.69 & 33.12 & 43.02 \\
\hline $\begin{array}{l}\text { Allied Bank } \\
\text { Limited }\end{array}$ & 4.36 & 9.33 & 70.83 & 3.33 & 45.47 & 0.378 & 86.04 \\
\hline $\begin{array}{l}\text { Bank Alfalah } \\
\text { Limited }\end{array}$ & 1.12 & 7 & 85.71 & 2.78 & 18.99 & 51.29 & 37.39 \\
\hline Bank Al Habib & 2.08 & 10 & 80 & 4.67 & 10.69 & 2.84 & 72.46 \\
\hline $\begin{array}{l}\text { Askari Bank } \\
\text { Limited }\end{array}$ & 0.5 & 10.89 & 74.42 & 3.33 & 0.075 & 2.03 & 50.65 \\
\hline $\begin{array}{l}\text { Meezan Bank } \\
\text { Limited }\end{array}$ & 0.81 & 10.33 & 80.56 & 3 & 2.44 & 0.28 & 88.73 \\
\hline $\begin{array}{l}\text { Standard Char- } \\
\text { tered Bank (Pak) }\end{array}$ & 0.92 & 7 & 58.93 & 3 & 0.0034 & 99.06 & 99.16 \\
\hline $\begin{array}{l}\text { Habib Metro- } \\
\text { politan Bank Ltd }\end{array}$ & 1.11 & 8.67 & 78.09 & 3 & 3.23 & 10.10 & 69.92 \\
\hline Faysal Bank Ltd & 0.83 & 8 & 79.12 & 3 & 0.034 & 13.56 & 65.57 \\
\hline $\begin{array}{l}\text { Summit Bank } \\
\text { Limited }\end{array}$ & 1.94 & 7.11 & 57.34 & 3 & 0.91 & 1.58 & 75.11 \\
\hline $\begin{array}{l}\text { Trust Investment } \\
\text { Bank Limited }\end{array}$ & 0.33 & 7.44 & 83.73 & 3.11 & 16.85 & 0 & 59.2 \\
\hline $\begin{array}{l}\text { JS Global Capital } \\
\text { Limited }\end{array}$ & 4.05 & 8 & 87.5 & 3.25 & 0.025 & 0.07 & 93.72 \\
\hline $\begin{array}{l}\text { Escorts Invest- } \\
\text { ment Bank Ltd }\end{array}$ & 0.67 & 7.89 & 77.03 & 3 & 20.49 & 0 & 71.02 \\
\hline $\begin{array}{l}\text { First National } \\
\text { Bank Modaraba }\end{array}$ & 0.69 & 7.12 & 58.93 & 3 & 0.02 & 0 & 55.16 \\
\hline Bank of Punjab & 0.31 & 9 & 82.44 & 3.14 & .001 & 2.50 & 69.32 \\
\hline $\begin{array}{l}\text { Soneri Bank } \\
\text { Limited }\end{array}$ & 0.71 & 8 & 87.5 & 2 & 1.28 & 6.07 & 56.13 \\
\hline
\end{tabular}

Note DPS = Dividend Per Share. 
